\title{
VERIFICATION OF EMPIRICAL FORMULAS FOR CALCULATING MEAN LOW FLOW WITH THE VIEW TO EVALUATING AVAILABLE WATER RESOURCES
}

\author{
Dariusz Piotr Młyński ${ }^{\bowtie}$, Andrzej Wałęga, Piotr Bugajski, Agnieszka Operacz, \\ Karolina Kurek
}

Faculty of Environmental Engineering and Land Surveying, Univeristy of Agriculture in Krakow, Al. Mickiewicza 21, 31-120 Kraków

\begin{abstract}
Aim of the study

In the present study, we aimed to verify empirical formulas for calculating mean low flow (MLF) with the view to evaluating available water resources for mountain catchments, located in the upper Vistula Basin. The following empirical formulas were analysed: Punzet and Stachý.
\end{abstract}

\begin{abstract}
Material and methods
The studies were conducted in the following stages: analysis of significant trends for low flows in the analysed catchments, followed by the mean low flows determination using the analysed methods, and the determination of available water resources in relation to MLF obtained from the various analysed methods.
\end{abstract}

\section{Results and conclusions}

The analysis of the results showed lack of statistically significant trends in the course of low flows for the analysed catchments. Also, the analysis indicated significant differences between MLF derived from hydrological data and that derived from empirical formulas. The obtained results indicated the need to update the empirical formulas for calculating MLF, particularly regarding the determination of available water resources in ungauged catchments, in relation to mean low flows.

Keywords: empirical formulas, mean low flow, available water resources

\section{INTRODUCTION}

Low flows $(L F)$, their course, and their impact on habitat conditions of aquatic ecosystems constitute a significant issue in hydrology and water management. These characteristics are the compound result of complex processes taking place in the catchment area - the processes, which are shaped by physiographic and meteorological conditions. Natural factors affecting the size and the course of $L F$ flows include: soil type, infiltration and hydraulic properties, aquifer level, vege- tation processes, and evaporation rate (Števková et al., 2012; Cupak, 2017; Cupak et al., 2017). The analysis of low flows, carried out both on an annual and multiannual basis, provides useful information and insight into the nature of water outflow from the catchment, as well as information used to study trends of outflow changes in the aspect of climate change (Kaznowska et al., 2015).

When analysing the use of surface water resources, hydrological calculations should be carried out in order to determine the amount of water available for

凶e-mail: dariusz.mlynski@gmail.com 
collection, while maintaining the so-called biological balance. Therefore, it is necessary to determine minimum flows $\left(Q_{n}\right)$ or environmental $(E F)$ flows, based on the characteristic flows for a given multi-year period (Młyński et al., 2015; Młyński and Wałęga, 2015; Operacz, 2015). The values of $Q_{n}$ flows form the basis for determining the size of available, renewable and non-renewable resources within the given catchment area. Currently, according to applicable legal norms in Poland, there is no reference method to determine its size (Wałęga et al., 2015). The Water Law Act of 20 July 2017 states that for individual water-legal permits, $Q_{n}$ flows constitute a defined part of mean low flows $(M L F)$, depending on the type of activity covered by the water-legal permit (Dz. U. 2017 item 1566).

In the case of controlled catchments, $M L F$ flows are determined using the direct method, based on observational series of daily low flows. In the uncontrolled catchments, $M L F \mathrm{~s}$ can be estimated based on the socalled empirical formulas, for instance, the Punzet formula, while bearing in mind certain limitations resulting from the applicability of the latter (Kokoszka, 2014). Empirical formulas constitute a generalization of information on flows collected for a larger number of water gauge profiles, by linking flow values with physiographic and meteorological factors influencing the outflow from the catchment (Wałęga and Młyński, 2015; Młyński et al., 2018).

The empirical formulas currently used in Poland for estimating $L F$ and $M L F$ flows have been developed mainly on the basis of hydrometric material from 1951-1980. Currently, they require verification or updating, which is directly related to the availability of more up-to-date as well as longer observational series of characteristic flows. Moreover, in the light of climatic changes as well as changes in land use within the catchment, the use of empirical formulas developed in the last century may raise justified doubts (Wałęga et al., 2014). Bearing in mind that $M L F$ flows constitute the basis for determining the volume of $Q_{n}$ flows used to estimate the reserve of water resources in a given region. The objective of this work was to verify the empirical formulas for estimating $M L F$ flows in the aspect of estimating $Q_{n}$ flows in selected mountain catchments of the Upper Vistula water region.

\section{DESCRIPTION OF THE STUDIED AREA}

The research was carried out for 10 mountain catchments located in southern Poland. The location of the studied catchments is shown in Figure 1. Table 1 shows the values of selected physiographic and meteorological characteristics of the catchment: $A$ - catchment area $\left(\mathrm{km}^{2}\right), I$ - incline of the main watercourse (-), $\mathrm{H}$ - medium height of the catchment (m), $N$ - soil non-permeability index (\%), $P$ - average annual atmospheric precipitation $(\mathrm{mm})$.

Table 1. Values of the investigated physiographic parameters for analysed catchments

\begin{tabular}{lccccc}
\hline \multicolumn{1}{c}{ River } & $\boldsymbol{A}, \mathbf{k m}^{2}$ & $\boldsymbol{I}, \mathbf{-}$ & $\boldsymbol{H}, \mathbf{m}$ & $\boldsymbol{N}, \mathbf{\%}$ & $\boldsymbol{P}, \mathbf{m m}$ \\
\hline $\begin{array}{l}\text { Woda } \\
\text { Ujsolska }\end{array}$ & 106.6 & 0.049 & 319.0 & 72 & 1005 \\
\hline Żabniczanka & 23.4 & 0.182 & 859.5 & 72 & 1094 \\
\hline Skawa & 123.7 & 0.015 & 564.5 & 77 & 840 \\
\hline Krzczonówka & 92.9 & 0.028 & 494.0 & 75 & 886 \\
\hline $\begin{array}{l}\text { Potok } \\
\text { Kościelski }\end{array}$ & 36.4 & 0.103 & 1210.0 & 75 & 1527 \\
\hline Lubieńka & 48.1 & 0.108 & 505.0 & 80 & 902 \\
\hline Mszanka & 174.0 & 0.030 & 553.0 & 81 & 944 \\
\hline $\begin{array}{l}\text { Kamienica } \\
\text { Nawojowska }\end{array}$ & 237.7 & 0.016 & 540.5 & 82 & 901 \\
\hline Sękówka & 122.7 & 0.023 & 547.0 & 84 & 791 \\
\hline Biała & 212.2 & 0.018 & 566.5 & 85 & 890 \\
\hline
\end{tabular}

\section{MATERIAL AND METHODS}

Data for the analysis, in the form of the observational series of daily flows $\left(Q_{d}\right)$ in the years 1985-2014, were obtained from the Institute of Meteorology and Water Management, of the National Research Institute in Warsaw. Subsequently, the studies were carried out according to the following stages: statistical verification of the significance of the $L F$ flow trend, determining the value of $M L F$ flows, determining the value of water reserves with a specific level of certainty. 


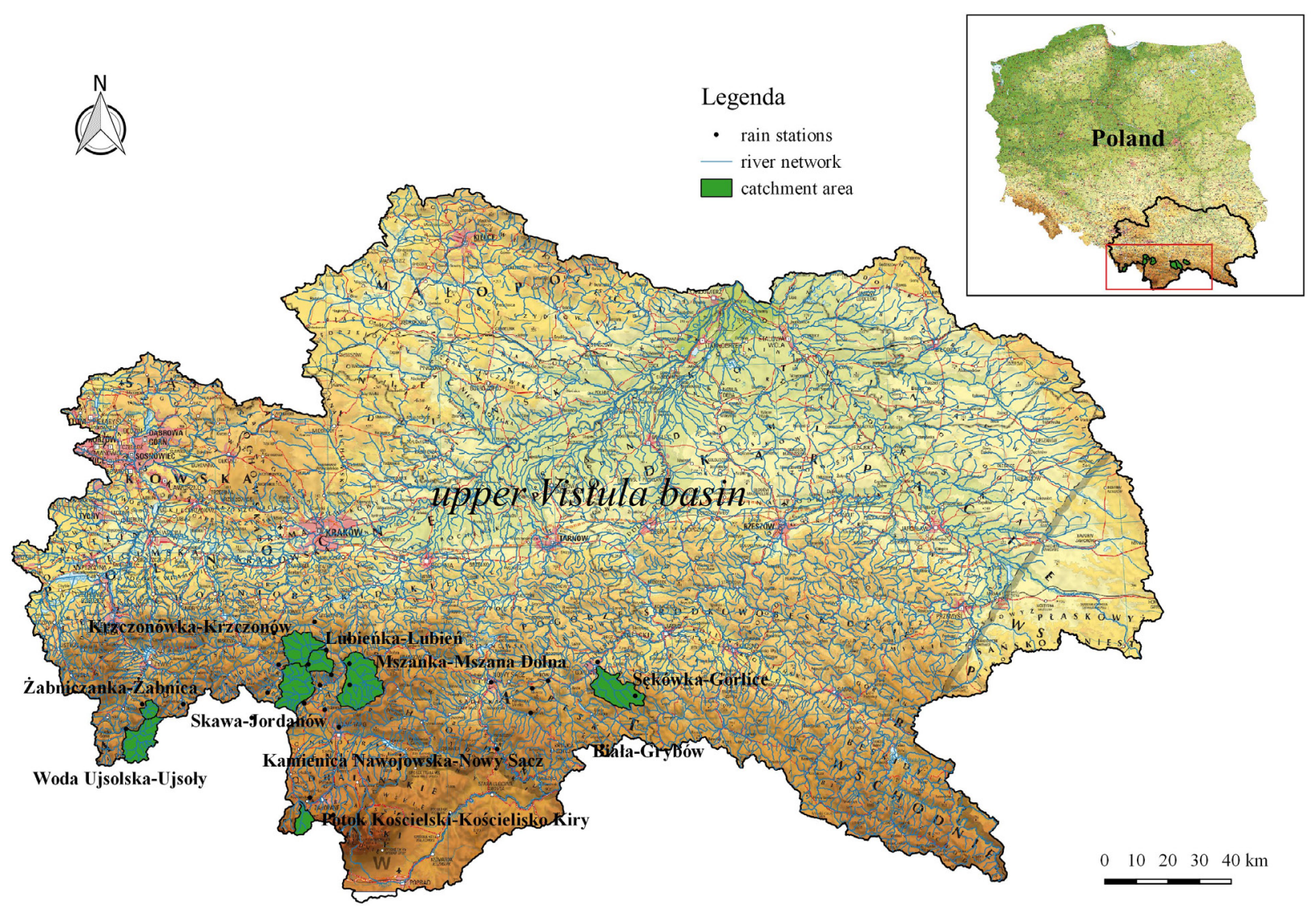

Fig 1. Location of investigated catchments in upper Vistula basin

\section{STATISTICAL VERIFICATION OF DATA}

Statistical verification of the data was performed with respect to $L F$ flows using the Mann-Kendall (MK) test. The zero hypothesis $\mathrm{H}_{0}$ of the test assumes no monotonic trend of the data, whereas the alternative hypothesis $\mathrm{H}_{1}$ states that such trend does exist. The calculations were carried out for the significance level of $\alpha=0.05$. Mann-Kendall's $S$ statistic was determined based on the following equation (Banasik and Hejduk, 2012; Rutkowska and Ptak, 2012):

$$
\begin{gathered}
S=\sum_{k=1}^{n-1} \sum_{j=k+1}^{n} \operatorname{sgn}\left(x_{j}-x_{k}\right) \\
\operatorname{sgn}\left(x_{j}-x_{k}\right)=\left\{\begin{array}{l}
1 \text { for }\left(x_{j}-x_{k}\right)>0 \\
0 \text { for }\left(x_{j}-x_{k}\right)=0 \\
-1 \text { for }\left(x_{j}-x_{k}\right)<0
\end{array}\right.
\end{gathered}
$$

where:

$n$ - number of elements in the time series.

Normalised $Z$ statistic was calculated from the following equation:

$$
Z=\frac{S-\operatorname{sgn}(S)}{\operatorname{Var}(S)^{1 / 2}}
$$

where:

$\operatorname{Var}(S)$ - variance $S$, determined from the equation:

$$
\operatorname{Var}(S) \frac{1}{18} \cdot(n \cdot(n-1) \cdot(2 \cdot n+5))
$$

The main assumption of the $M K$ test applied here is the lack of autocorrelation in a series of data. In the case of the analysis of $L F$ flows, such correlations may occur, which in turn leads to an underestimation of the variance $\operatorname{Var}(\mathrm{S})$. Therefore, an adjustment for variance 
correction is included, calculated only for data with significant partial autocorrelation (Baran-Gurgul and Raczyński, 2017; Młyński et al., 2018):

$$
\operatorname{Var} *(S)=\operatorname{Var}(S) \cdot \frac{n}{n_{s}^{*}}
$$

where:

$$
\frac{n}{n_{s}^{*}}-\text { effective number of observations, calculated }
$$

$$
\begin{aligned}
& \frac{n}{n_{s}^{*}}=1+\frac{2}{n(n-1)(n-2)} . \\
& \cdot \sum_{k=1}^{n-1}(n-k)(n-k-1)(n-k-2) \rho_{k}
\end{aligned}
$$

where:

$$
\begin{aligned}
k & \text { - adjustment; } \\
\rho_{k} \text { - value of the next significant autocorrelation } & \\
& \text { coefficient. }
\end{aligned}
$$

\section{DETERMINING THE VALUE OF MEAN LOW FLOWS}

The average $M L F$ flows were determined based on the observational series of $Q_{d}$ flows for the investigated catchments in the years 1985-2014 (direct method) and using empirical formulas: Punzet's and Stachý's. The Punzet formula for estimating $M L F$ flows in mountainous catchments is as follows (Punzet, 1981):

$$
M L F=10^{-3} \cdot M L F \cdot A, m^{3} \cdot s^{-1}
$$

where:

$$
\begin{aligned}
& M L F \text { - unit mean low flow }\left[\mathrm{dm}^{3} \cdot \mathrm{s}^{-1} \cdot \mathrm{km}^{-2}\right] \\
& A \quad \text { - catchment area }\left[\mathrm{km}^{2}\right] .
\end{aligned}
$$

The unit mean low flow is estimated as follows:

$$
M L F=0.00807 \cdot H^{1.21815} \cdot P^{0.1722} \cdot I^{0.3273} \cdot N^{-1.0504}
$$

where:

$H$ - mean height of the catchment [m.a.s.1.];

$P$ - mean annual precipitation in the catchment $[\mathrm{mm}]$;

$I$ - longitudinal incline of the watercourse $[\mathrm{m}$. $\mathrm{km}^{-1}$;

$N$ - Boldakov's soil non-permeability index [\%].
Stachý's formula for calculating $M L F$ flows in Carpathian catchments is described by the following correlation (Stachý, 1990):

$M L F=2.613 \cdot 10^{-4} \cdot A^{1.07} \cdot S S q_{p}^{0.55} \cdot i_{r}^{0.35}, \mathrm{~m}^{3} \cdot \mathrm{s}^{-1}$

where:

A - catchment area $\left[\mathrm{km}^{2}\right]$;

$S S q_{p}$ - unit mean flow from the multiyear period from groundwater flow $\left[\mathrm{dm}^{3} \cdot \mathrm{s}^{-1} \cdot \mathrm{km}^{-2}\right]$;

$i_{r} \quad-$ incline of the watercourse $\left[\mathrm{m} \cdot \mathrm{km}^{-1}\right]$.

In order to determine individual physiographic characteristics of the catchment, the QGIS 2.18 software was used. The areas of the investigated catchment $(A)$ have been determined on the basis of the Map of the Hydrographic Division of Poland (MPHP 2010). Mean catchment height $(H)$ and inclines of the watercourse $(I),\left(i_{r}\right)$ were determined based on the Map of Hydrographic Division of Poland and on the Digital Terrain Model (NMT), obtained from the United States Geological Survey, with a grid resolution of about $30 \mathrm{~m}$. Mean annual precipitation in the catchment $(P)$ was determined using the reverse distance method based on meteorological data, in the form of observation series of daily precipitation, in the years 1985-2014, obtained from the Institute of Meteorology and Water Management of the National Research Institute in Warsaw. The mean unit flow from underground water supply $S S q_{p}$ was determined based on the Hydrological Atlas of Poland (Stachý, 1987).

In order to verify the analysed empirical formulas, the values of the relative error of estimation $\sigma$ of $M L F$ flows were determined using the Punzet and Stachý formula:

$$
\sigma=\frac{M L F_{e}-M L F}{M L F} \cdot 100, \%
$$

where:

$$
\begin{aligned}
M L F_{e}- & \text { mean low flow calculated from empirical } \\
& \text { formulas }\left[\mathrm{m}^{3} \cdot \mathrm{s}^{-1}\right] \\
M L F- & \text { mean low flow calculated on the basis of } \\
& \text { hydrometric observations }\left[\mathrm{m}^{3} \cdot \mathrm{s}^{-1}\right] .
\end{aligned}
$$

Above-zero values of relative errors indicate the overestimation of $M L F$ flows determined using the formulas analysed herein, as compared to hydrometric 
observations. Below-zero $\sigma$ error values indicate underestimation of $M L F$ flows calculated with empirical formulas, in comparison to hydrometric observations.

\section{DETERMINING WATER RESERVE WITH A SPECIFIED LEVEL OF CERTAINTY}

Available water resources (water reserve) were determined as the difference between the characteristic flow and the baseflow (Ciepielowski, 1999). Because water reserve with a given level of certainty were analysed, their value in the studied catchments was calculated as:

$$
Z D=Q_{g w-95 \%}-Q_{n h}, \mathrm{~m}^{3} \cdot \mathrm{s}^{-1}
$$

where:

$$
\begin{aligned}
& \begin{aligned}
Q_{g w=95 \%}- & \text { flows with the probability of } 95 \% \\
& {\left[\mathrm{~m}^{3} \cdot \mathrm{s}^{-1}\right] ; }
\end{aligned} \\
& \begin{array}{c}
Q_{n h}-\text { baseflow }\left[\mathrm{m}^{3} \cdot \mathrm{s}^{-1}\right] .
\end{array}
\end{aligned}
$$

In this work, the amount of water reserves for municipal supply purposes was adopted - hence a 95\% certainty level was assumed (Szpindor, 1974). $Q_{g w}=95 \%$ flows were determined based on the course of multiyear flow guarantee curves, designated for the studied catchments. The baseflow was calculated using the following formula (Kostrzewa, 1977):

$$
Q_{n h}=k \cdot M L F, \mathrm{~m}^{3} \cdot \mathrm{s}^{-1}
$$

where:

$k \quad$ - parameter depending on the hydrological type of the river, and the surface area of the catchment [-];

$M L F$ - mean low flows determined based on the hydrometric material and verified empirical formulas $\left[\mathrm{m}^{3} \cdot \mathrm{s}^{-1}\right]$.

\section{RESEARCH RESULTS AND THEIR ANALYSIS}

In the first stage of the study, an analysis of the statistical significance of the $L F$ flow trend was conducted, using the Mann-Kendall test for the studied catchments in the multi-year period 1985-2014. The results of the analysis are summarized in Table 2.

Based on the results summarized in Table 2, it was found that for the analysed multi-year period there has been no significant statistical trend of $L F$ flows in the studied catchments. This is confirmed by the $p_{c}$ value of the Mann-Kendall test, in each case at a level above $5 \%$. Lack of statistically significant trends means that

Table 2. Results of the statistical analysis conducted by applying MK test to the investigated catchments

\begin{tabular}{lccccccc}
\hline \multicolumn{1}{c}{ River } & $\boldsymbol{Z}_{\boldsymbol{c}}$ & $\boldsymbol{p}_{\boldsymbol{c}}$ & $\boldsymbol{V a r}(\boldsymbol{S})_{\boldsymbol{c}}$ & $\boldsymbol{n} / \boldsymbol{n}^{*}$ & $\boldsymbol{Z}$ & $\boldsymbol{p}$ & $\boldsymbol{V} \boldsymbol{\operatorname { a r } ( \boldsymbol { S } )}$ \\
\hline Woda Ujsolska & 1.039 & 0.299 & 2700.458 & 0.863 & 0.965 & 0.334 & 3128.333 \\
\hline Żabniczanka & 0.542 & 0.588 & 1363.483 & 0.441 & 0.360 & 0.719 & 3089.667 \\
\hline Skawa & -0.564 & 0.573 & 1258.857 & 0.404 & 0.358 & 0.720 & 3119.000 \\
\hline Krzczonówka & 0.599 & 0.549 & 1885.149 & 0.602 & 0.465 & 0.642 & 3131.000 \\
\hline Kirowa Woda & 2.938 & 0.003 & 704.755 & 0.225 & 1.394 & 0.163 & 3133.000 \\
\hline Lubieńka & -0.493 & 0.622 & 1487.829 & 0.477 & -0.340 & 0.734 & 3116.000 \\
\hline Mszanka & -1.821 & 0.069 & 2027.701 & 0.647 & -1.465 & 0.143 & 3133.000 \\
\hline Kamienica & -0.257 & 0.797 & 739.622 & 0.236 & -0.125 & 0.901 & 3134.667 \\
Nawojowska & 1.313 & 0.189 & 794.242 & 0.254 & 0.662 & 0.508 & 3124.667 \\
\hline Sękówka & -1.407 & 0.159 & 1163.542 & 0.375 & -0.862 & 0.389 & 3099.667 \\
\hline Biała & & & & &
\end{tabular}

$Z_{c}$ - modified value of the normalised MK statistic; $p_{c}$ - modified value of the test probability, $\operatorname{Var}(S)_{c}-$ modified value of the variance, $n / n^{*}$ - effective number of observations, $Z$ - the value of the normalised MK statistic, $p$ - test probability, $\operatorname{Var}(S)-$ variance 
the investigated random variables derive from the same general population. Thus, in the analysed multiyear period, no factor appeared to be significantly affecting the processes that shape low flows. The results obtained from the research can be linked to the results concerning the trend analysis of the factors significantly affecting the flow of waters in the catchments of the Upper Vistula water region. Research carried out by Pińskwar (2010) and Niedźwiedź et al. (2014) showed no significant trends regarding the indicators describing daily precipitation. Analyses carried out by Falarz (2002) confirmed the lack of significant trends for the duration of snow cover remaining in mountainous catchments. The supply of rivers in the Upper Vistula water region comes mainly from snowmelt runoff and from precipitation - hence it is assumed that the rhythm of effluents is repeated by the low flows.

To estimate the value of $M L F$ flows, hydrometric material and empirical formulas of Punzet and Stachý were used. The results of the calculations and of the empirical formulas verification are summarized in Table 3 and Figure 2.

Based on the value of $M L F$ flows compiled in Table 3 and Figure 2, significant differences were found between the analysed characteristics. In the case of $M L F$ flows calculated using the Punzet formulas, most of them are higher than the $M L F$ determined using the direct method. Values of relative errors in estimating the $M L F$ flow with the Punzet formula ranged between $5.6 \%$ (for Lubieńka) and -73.9\% (for the Biała river). The average relative error amounted to $43.4 \%$. The $M L F$ flows calculated using the Stachý formula were in most cases lower than the actual values. The relative errors in determining the $M L F$ flow with the Stachý formula ranged from 3.8\% (for Woda Ujsolska) to $-205.4 \%$ (for Skawa), with the mean value of $54.9 \%$.

Table 3. Values of mean low flows calculated by direct method and by empirical formulas

\begin{tabular}{lccc}
\hline \multirow{2}{*}{$\begin{array}{c}\text { River-cross- } \\
\text { section }\end{array}$} & $M L F, \mathrm{~m}^{3} \cdot \mathrm{s}^{-1}$ & \multicolumn{2}{c}{$\begin{array}{c}\text { Calculated } M L F, \\
\mathrm{~m}^{3} \cdot \mathrm{s}^{-1}\end{array}$} \\
\cline { 3 - 4 } Woda Ujsolska & 0.300 & 0.123 & 0.288 \\
\hline Zunzet & Stachý \\
\hline Skawniczanka & 0.093 & 0.141 & 0.132 \\
\hline Krzczonówka & 0.108 & 0.177 & 0.330 \\
\hline Potok Kościelski & 0.240 & 0.142 & 0.299 \\
\hline Lubieńka & 0.415 & 0.279 & 0.270 \\
\hline Mszanka & 0.117 & 0.111 & 0.238 \\
\hline Kamienica & 0.467 & 0.291 & 0.597 \\
\hline Nawojowska & 0.478 & 0.307 & 0.456 \\
\hline Sękówka & 0.241 & 0.173 & 0.171 \\
\hline Biała & 0.163 & 0.292 & 0.283 \\
\hline
\end{tabular}

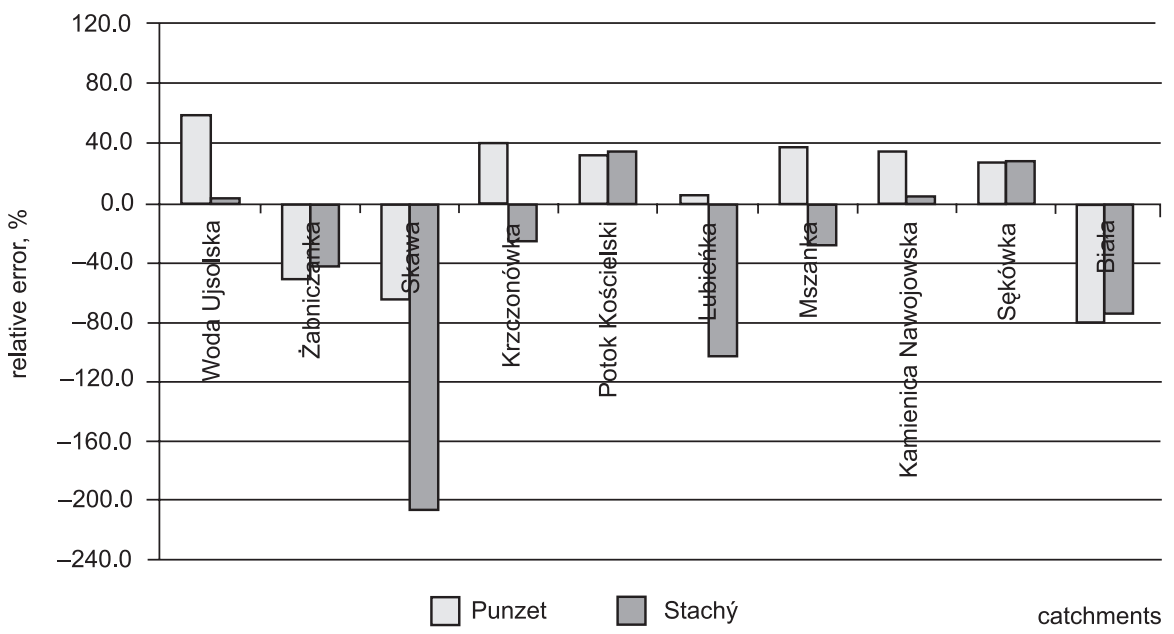

Fig. 2. Mean relative errors in mean low flows derived by empirical formulas 
The obtained results of the verification of empirical formulas for calculating $M L F$ flows may be due to the fact that these formulas are dedicated mainly to natural catchments, i.e. those in which the outflow is not disturbed by anthropogenic pressure. The catchments under investigation are located in southern Poland - that is within an area where the impact of human activity on the river regime in recent decades was particularly significant. This applies mainly to mountainous basins, which very often are characterized by a significant concentration of human pressure, such as surface water intakes, water discharges, or the introduction of hydro-technical structures (RZGW, 2012). When analysing the obtained results, it should also be emphasized that due to the on-going meteorological changes and changes to the land use within the catchment, as well as the availability of longer and more current series of characteristic flows, empirical formulas should be systematically verified and updated. It also needs to be stressed that the number of independent variables in the model should be optimal. In addition to carrying the information about the value of the dependent variable, each independent variable is also burdened with uncertainty resulting from the observation series of such a characteristic. Furthermore, let us point out that empirical formulas should be constructed in the possible way from a methodological point of view. This statement refers to the fact that the currently used formulas were developed in times of limited access to digital computing techniques. This meant limiting the possibilities of their analysis in terms of the quality of the obtained results. Moreover, we should take into account the development of measurement technologies used to acquire land data as well as of spatial information systems that allow for the automatic calculation of the physiographic parameters of the catchment, which then form the basis for the development and use of empirical models for calculating characteristic flows. In addition, attention should be paid to the fact concerning the increasing possibility of obtaining current hydro-meteorological data. The application of spatial information systems, together with the use of current hydro-meteorological data, allows for a more accurate estimation of characteristic flows than in had been the case with traditional materials (topographic maps, hydrological and meteorological atlases) used in previous years, when estimating flows using empirical formulas (Węglarczyk, 2015).

A complement to the conducted research was the analysis of available resources with a $95 \%$ certainty $\left(Z D_{g w}=95 \%\right)$, where baseflows were estimated on the basis of $M L F$ calculated using the direct method as well as the Punzet and Stachý models. The results obtained from the analysis are summarized in Table 4. Figure 3 shows the number of inhabitants that it is possible to supply with water, with the available resources calculated by the analysed methods.

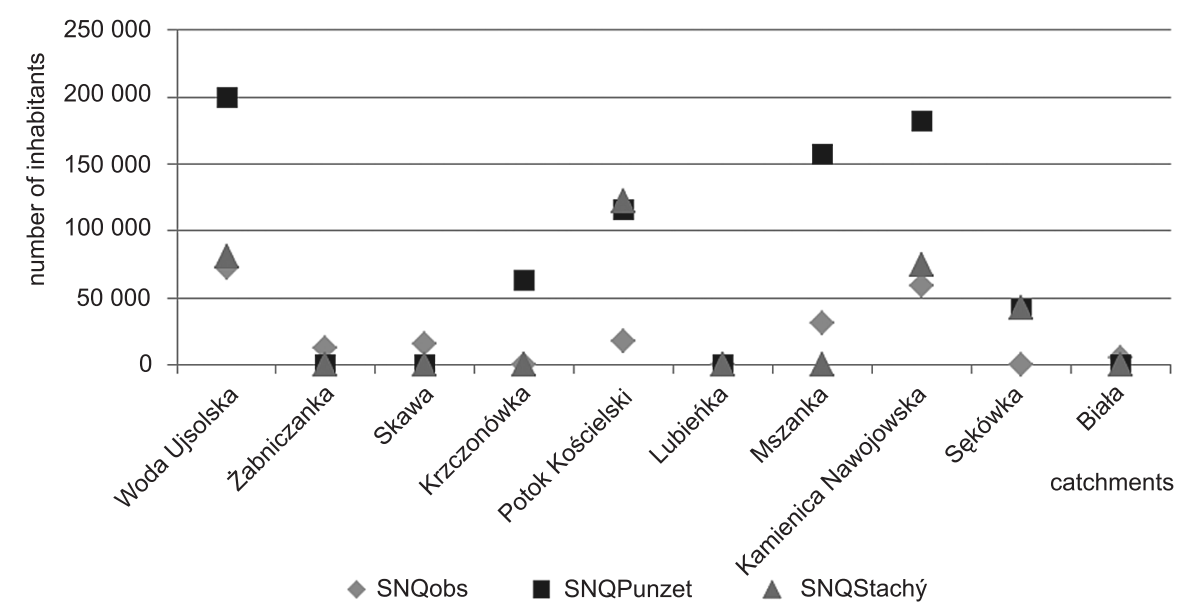

Fig. 3. Number of inhabitants that it is possible to supply with water from available water resources derived regarding to mean low flow obtained from analysed methods 
Table 4. Available water resources derived based ion mean low flows obtained from the analysed methods

\begin{tabular}{lccc}
\hline \multicolumn{1}{c}{ River } & $\begin{array}{c}Z D \\
{\left[\mathrm{~m}^{3} \cdot \mathrm{s}^{-1}\right]}\end{array}$ & $\begin{array}{c}Z D_{\text {Punzet }} \\
{\left[\mathrm{m}^{3} \cdot \mathrm{s}^{-1}\right]}\end{array}$ & $\begin{array}{c}Z D_{\text {Stachý }} \\
{\left[\mathrm{m}^{3} \cdot \mathrm{s}^{-1}\right]}\end{array}$ \\
\hline Woda Ujsolska & 0.100 & 0.277 & 0.112 \\
\hline Żabniczanka & 0.017 & -0.031 & -0.022 \\
\hline Skawa & 0.022 & -0.047 & -0.200 \\
\hline Krzczonówka & -0.010 & 0.088 & -0.069 \\
\hline Potok Kościelski & 0.025 & 0.161 & 0.170 \\
\hline Lubieńka & -0.007 & -0.001 & -0.128 \\
\hline Mszanka & 0.043 & 0.219 & -0.087 \\
\hline Kamienica & 0.082 & 0.253 & 0.104 \\
Nawojowska & -0.011 & 0.057 & 0.059 \\
\hline Sękówka & 0.007 & -0.122 & -0.113 \\
\hline Biała & & &
\end{tabular}

$Z D$ - available resources determined based on the $M L F$, using statistical method; $Z D_{\text {Punzet }}$ - available resources determined based on the $M L F$, calculated using the Punzet's formula; $Z D_{\text {Stachy }}$ - available resources determined based on the $M L F$, calculated using the Stachý's formula

Based on the values in Table 4, it was found that $Z D_{g w=95 \%}$ determined on the basis of $M L F$ flows, estimated with the Punzet formula, in 6 studied catchments are higher than the $Z D_{g w=95 \%}$ determined on the basis of hydrometric observations. On the other hand, the negative values of these resources were recorded for the 4 catchments, where only for Lubieńka in Lubien section is the result supported by hydrometric observations. In the case of $Z D_{g w=95 \%}$ determined on the basis of $M L F$ flows, calculated using the Stachý formula, higher values of these resources were found in 4 studied catchments, as compared to resources determined on the basis of hydrometric material. In contrast, in 6 analysed catchments, negative values of these resources were found, where only for the 2 basins is this is convergent with the values obtained on the basis of hydrometric material. It should be emphasized that the variable size of available resources, determined on the basis of the analysed methods, affects a significant diversification of the potential number of inhabitants that it is possible to supply with water from surface water sources (see: Fig. 3). This underscores the problem of estimating baseflows in relation to the $M L F$ in uncontrolled catchments. It should be noted that obtaining higher values of $M L F$ flows using empirical formulas would lead to the determination of $Q_{n h}$ flows at too high a level. This is beneficial in terms of environmental considerations - however, it may cause a barrier to socio-economic development within the given catchment (Operacz et al., 2018). In addition to the significant impact on the quantitative status of the catchment's water resources, the $M L F$ is assumed to be the measure for assessing the possibility of introducing a specific amount of sewage into the receiving body of water, which is a measurable aspect in the quality assessment of such a facility (Kurek et al., 2018). Therefore, it would be justified to conduct analyses related to establishing and verifying current methods for calculating $M L F$ flows in uncontrolled catchments.

\section{CONCLUSIONS}

Based on the conducted analyses, it was found that in the examined multi-year period there were no factors significantly affecting the formation of low flows, in the investigated catchments of the upper Vistula water region. This is evidenced by the lack of statistically significant trends for $L F$ flows in the analysed catchments. The obtained results also indicated that there is a need to update empirical formulas for calculating $M L F$ flows in mountainous catchments. In conducting such research, anthropogenic pressure for the analysed areas should be taken into account. This is confirmed by the value of relative errors in the estimation of $M L F$ flows in relation to flows calculated using the direct method. In addition, it was found that after considering the baseflow, which takes into account $M L F$ calculated by the analysed methods, the available resources for the same catchments were different for different computation methods. This contributes to the problems associated with the determination of resources for ungauged catchments, where they can be set at a too high or too low a level in relation to the actual flow conditions. Therefore, it is necessary to conduct further analyses regarding obtaining reliable values of $M L F$ flows in ungauged catchments. 


\section{REFERENCES}

Banasik, K., Hejduk, L. (2012). Long term changes in runoff from a small agricultural catchment. Soil and Water Research, 7(2), 64-72.

Baran-Gurgul, K., Raczyński, K. (2017). Dynamika występowania niżówek w rzekach górskich i wyżynnych na przykładzie Wisłoki i górnego Wieprza. Cz. 2. Zmienność wieloletnia. Woda-Środowisko-Obszary Wiejskie, 17(1), 5-17.

Ciepielowski, A. (1999). Podstawy gospodarowania wodą. Warszawa: Wyd. SGGW.

Cupak, A. (2017). The initial results of nonhierarchical cluster methods use for low flow grouping. Journal of Ecological Engineering, 18(2), 44-50.

Cupak, A., Wałęga, A., Michalec, B. (2017). Cluster analysis in determination of hydroloically homogeneous regions with low flow. Acta Scientiarum Polonorum Formatio Circumiectus, 16(1), 53-63.

Falarz, M. (2002). Long-term variability in reconstructed and observed snow coverover the last 100 winter seasons in Cracow and Zakopane (southern Poland), Clim. Res., 19, 247-256.

Kaznowska, A., Hejduk, A., Hejduk, L. (2015). Charakterystyka występowania wezbrań i niżówek w małej zlewni niziny mazowieckiej. Woda-Środowisko-Obszary Wiejskie, 15(3), 45-59.

Kokoszka, R. (2014). Obliczenia hydrologiczne w warunkach korzystania z wód regionów wodnych Górnej Wisły, Czarnej Orawy i Dniestru. Acta Scientiarum Polonorum Formatio Circumiectus, 13(4), 141-153.

Kostrzewa, H. (1977). Weryfikacja kryteriów i wielkości przepływu nienaruszalnego dla rzek Polski. Warszawa: Wyd. IMGW.

Kurek, K., Bugajski, P., Młyński, D., Nowobilska-Majewska, E. (2019). The impact of treated sewage on water quality in Mordarka stream. Journal of Ecological Engineering, 20(1), 39-45.

Młyński, D., Kurek, K., Bugajski, P. (2018). An analysis of seasonal waste draining for the urban agglomeration using statistical methods. Water, 10, 976-989.

Młyński, D., Wałęga, A. (2015). Analiza możliwości wykorzystania metody Tennanta do wyznaczania przepływu środowiskowego w zlewni górskiej. Episteme, 26 (1), 323-332.

Młyński, D., Wałęga, A., Petroselli, A. (2018). Verification of empirical formulas for calculating annual peak discharge with specific return period in the upper Vistula basin. Acta Scientiarum Polonorum Formatio Circumiectus, 17(2), 145-154.
Młyński, D., Wałęga, A., Wachulec, K. (2015). Porównanie metod do wyznaczania przepływu środowiskowego na przykładzie zlewni górskiej. Inżynieria Ekologiczna, 44, 184-190.

Niedźwiedź, T., E. Łupikasza, I. Pińskwar, Z.W. Kundzewicz, M. Stoffel, and Ł. Małarzewski. (2014). Climatological background of floods at the northern foothills of the Tatra Mountains. Theoretical and Applied Climatology, 119, 273-284.

Operacz, A., Wałęga, A., Cupak, A., Tomaszewska, B. (2018). The comparison of environmental flow assessment - the barrier for investment in Poland or river protection? Journal of Cleaner Production, 193, 575-592.

Operacz, A. (2015). Wyznaczanie wartości przepływu nienaruszalnego $\mathrm{w}$ inwestycjach związanych $\mathrm{z}$ wodami powierzchniowymi według metody Kostrzewy. Ekonomia i Środowisko, 1(52), 100-109.

Pińskwar, I. (2010). Projekcje zmian w ekstremach opadowych w Polsce. Monografie Komitetu Gospodarki Wodnej PAN. Warszawa: PAN.

Punzet, J. (1981). Empiryczny system ocen charakterystycznych przepływów rzek i potoków w karpackiej części Dorzecza Wisły. Wiadomości IMGW, 1-2, 31-39.

Rutkowska, A., Ptak, M. (2012). On certain stationary tests for hydrological series. Studia Geotechnica et Mechanica, 4, 51-63.

RZGW. (2015). Identyfikacja znaczących oddziaływań antropoegenicznych w obszarze działania RZGW w Krakowie (regiony wodne: Górna Wisła, Czarna Orawa i Dniestr). Kraków.

Stachý, J. (1990). Przepływy średnie niskie MLF jako miarodajna charakterystyka projektowa. Przegląd Geofizyczny, 1-2, 45-54.

Stachý, J. (red.) (1987). Atlas hydrologiczny Polski. Warszawa: Wydawnictwo Geologiczne.

Števková, A. Sabo M. Kohnová S. (2012). Pooling of low flow regimes using cluster and principal component analysis. Slovak Journal of Civil Engineering., 20(2), 19-27.

Szpindor, A. (1974). Gospodarka Wodna. Warszawa: Wyd. PWN.

Ustawa z dnia 20 lipca 2017 r. Prawo wodne (Dz. U. 2017 poz. 1566).

Wałęga, A., Młyński, D. (2015). Weryfikacja wzoru Punzeta do wyznaczania przepływów maksymalnych prawdopodobnych w rzece górskiej i równinnej w dorzeczu górnej Wisły. Infrastruktura i Ekologia Terenów Wiejskich, 4(1), 873-885.

Wałęga, A., Młyński, D., Kokoszka, R. (2014). Weryfikacja wybranych metod empirycznych do obliczania prze- 
pływów minimalnych i średnich w zlewniach dorzecza Dunajca. Infrastruktura i Ekologia Terenów Wiejskich, 2(3), 825-837.

Wałęga, A., Młyński, D., Kokoszka, R., Miernik, W. (2015). Possibilities of applying hydrological methods for determining environmental flows in select catchments of the upper Dunajec basin. Polish Journal of Environmental Studies, 24(6), 2663-2676.

Węglarczyk, S. (2015). Osiem powodów konieczności rewizji stosowanych w Polsce wzorów na maksymalne roczne przepływy o zadanym prawdopodobieństwie przewyższenia. Gospodarka Wodna, 11, 323-328.

\section{WERYFIKACJA WZORÓW EMPIRYCZNYCH DO WYZNACZANIA PRZEPŁYWÓW ŚREDNICH NISKICH W ASPEKCIE SZACOWANIA ZASOBÓW DYSPOZYCYJNYCH}

\section{ABSTRAKT}

\section{Cel pracy}

Celem pracy była weryfikacja wzorów empirycznych do wyznaczania przepływów średnich niskich (SNQ) w aspekcie szacowania zasobów dyspozycyjnych, dla wybranych zlewni górskich Polski południowej. Analizie poddano wzory empiryczne Punzeta i Stachý.

\section{Materiat i metody}

Badania wykonano wg następujących etapów: analiza istotności trendu przepływów niskich $(N Q)$, określenie wartości przepływów $S N Q$ metodą bezpośrednią oraz wzorami Punzeta i Stachý, wyznaczenie zmienności zasobów dyspozycyjnych w odniesieniu do przepływu $S N Q$ wyznaczonego różnymi metodami.

\section{Wyniki i wnioski}

Na podstawie przeprowadzonych badań stwierdzono brak statystycznie istotnych trendów przepływów $N Q$ w zlewniach badawczych. Wskazano na znaczne różnice pomiędzy wartościami przepływów, określonymi za pomocą wzoru Punzeta i Stachý, w odniesieniu do przepływu $S N Q$ wyznaczonego na bazie materiału hydrometrycznego,

Stowa kluczowe: wzory empiryczne, przepływ średni niski, zasoby dyspozycyjne 